\title{
DARWIN'S ORCHIDS: THEIR VARIATION, PLASTICITY, AND NATURAL SELECTION
}

\author{
James D. Ackerman ${ }^{1,4}$, Mariely Morales² \& Raymond Tremblay ${ }^{3}$ \\ ${ }^{1}$ Department of Biology and Center for Applied Tropical Ecology and Conservation, \\ University of Puerto Rico, P. O. Box 23360, San Juan PR 00931-3360, U.S.A. \\ ${ }^{2}$ Department of Biology, University of Puerto Rico, P.O. Box 23360, San Juan PR 00931-3360, U.S.A. \\ ${ }^{3}$ Department of Biology, University of Puerto Rico, Humacao, PR 00791-4300, U.S.A., and Center for \\ Applied Tropical Ecology and Conservation, University of Puerto Rico, San Juan, PR 00931, U.S.A. \\ ${ }^{4}$ Author for correpondence: ackerman.upr@gmail.com;
}

\begin{abstract}
Patterns of variation and their fitness consequences are critical in revealing natural selection. One of the most variable groups of plants are the deception-pollinated orchids, pollinators of which are deceived in their search for a food reward. Negative frequency-dependent selection and disruptive selection have been suggested as the means by which high levels of variation are maintained, yet in most cases such selection has not been detected, prompting alternative explanations including genetic drift. Could phenotypic plasticity cloud the effects of selection? Using a Tolumnia variegata population as a model system, we conducted a reciprocal transplant experiment to determine the effects of light environment on vegetative, inflorescence, and floral characteristics over multiple seasons. The results were complex and showed significant responses to light for most traits measured, but often those changes were obscured by variable responses across years, likely a consequence of dramatically different rainfall. Fruit production was similar for sun and shade sites, but trajectories of selection on a given trait between the two sites were often incongruent. Our data indicated that selection in a heterogeneous environment can indeed be blunted by phenotypic plasticity, but not all characters respond in the same way.
\end{abstract}

RESUMEN. Las consecuencias de los patrones de variación en el éxito de una planta son críticas para revelar la selección natural. Uno de los grupos más variados de plantas son las orquídeas que llevan a cabo polinización por engaño las mismas engañan a los polinizadores los cuales buscan una recompensa alimentaria en ellas. La selección negativa dependiente de frecuencia y la selección disruptiva han sido sugeridas para explicar el mantenimiento de altos niveles de variación. En la mayoría de los casos estas selecciones no han sido detectadas, provocando otras explicaciones alternas como la deriva genética. ¿Podrá la selección natural ser nublada por la plasticidad fenotípica? Usando poblaciones de Tolumnia variegata como sistema modelo, nosotros realizamos un experimento de trasplante recíproco para determinar los efectos de la luz en las características de la parte vegetativa, inflorescencia y flores, a través de diferentes épocas del año. Los resultados fueron complejos, la mayoría de los rasgos medidos presentaron respuestas significativas a la luz, pero la mayoría de estos cambios fueron obscurecidos por respuestas variadas a través de los años, probablemente por una diferencia dramática en la precipitación. La producción de frutos fue similar entre sitios de sombra y sol, pero las trayectorias de selección de las características entre los dos lugares fueron en su mayoría incongruentes. Nuestros datos indican que la selección en un ambiente heterogéneo puede ser disfrazada por la plasticidad fenotípica, pero no todas las características responden de la misma manera.

KEY wORDS: Orchidaceae, Charles Darwin, floral variation, deceipt-pollination, natural selection

One hundred and fifty years ago, Darwin published his treatise, On the Origin of Species by Means of Natural Selection. Unquestionably, this was a landmark event that shook the tenets of science and western society. This 450-page abstract established the foundation for evolutionary theory by describing the process by which change may occur through natural selection (Darwin, 1859). As the story has been told so 
many times from a plethora of perspectives, Darwin was slow to amass supporting data and was pushed to come forth with his thesis when Alfred Russel Wallace wrote to him expressing essentially the same ideas (Wallace, 1858). Although Darwin did not reach the biological diverse regions of the tropical Andes, he was strongly influenced by his visit to another part of Ecuador: the Galapagos Islands (Darwin, 1845). From those studies and many others throughout the world he developed a sense of natural history perhaps unmatched by all those who preceded him and those who followed.

Over time, we have come to know Darwin's theory of natural selection quite well and have been able to enrich it with accumulated knowledge of biology, especially with a better understanding of genetics. Natural selection is now viewed as a process with three conditions. First, a population must have variation, a cornerstone to the theory thoroughly appreciated by Darwin, though he did not know the genetic basis for it. Secondly, variants within a population must show differential reproductive success, also known as fitness. And finally, the traits in question must be heritable. All three ideas were well developed by Darwin, which is remarkable considering modern genetics had not yet arrived. If all three conditions are met, then natural selection ensues with a predictable outcome (Endler, 1986).

Darwin did note that much variation came from cross-fertilization and that many plant traits were adaptations that ensured or enhanced the probability for cross-pollination. The amount of data he accumulated on this was prodigious, and his favorite model system was unquestionably orchids. He left the orchids out of the Origin of Species, but the first book published after his landmark treatise was On the Various Contrivances by which British and Foreign Orchids Are Fertilised by Insects, a compendium of pollination mechanisms associated with ensuring cross-fertilization (Darwin, 1862). He regarded those mechanisms, some quite fantastic, as a consequence of the advantages for cross-pollination. Such observations are convincing, although they merely represent indirect evidence for natural selection.

The mechanisms for cross-fertilization abound in plants, but Darwin knew that it was insufficient simply to catalogue them, that he also had to show what the advantage was. Out came yet another book in support of his theory of natural selection: The Effects of Cross and Self Fertilisation in the Vegetable Kingdom (Darwin, 1876). With meticulous garden experiments on a variety of plants, Darwin demonstrated that cross-fertilization produced strong, variable offspring, whereas repeated self-fertilization produced progressively fewer and weaker progeny, a trend that could be reversed with a return to cross-fertilization. We interpret the results of selfing as simply inbreeding depression, though Darwin expressed it more elegantly in the flowery language of the time: "It is hardly an exaggeration to say that Nature tells us, in the most emphatic manner, that she abhors perpetual selffertilisation" (Darwin, 1862).

\section{Orchids and floral variation}

Orchids are not only an ideal model system to elucidate the remarkable adaptations associated with cross-pollination, but they are also ideal because they are perhaps the most species-rich family of flowering plants. This diversity has often been attributed to adaptive radiation associated with diverse pollination biology. Although the family is relatively old (Ramírez et al., 2007), we perceive it as a dynamic group where natural selection should be pervasive.

Unlike Ponce de León, some evidence indicates that orchids have found the fountain of youth where diversification remains an active process: their populations often show considerable variation, one of the basic conditions for natural selection. Flowers may vary in size, shape, color, and even fragrance (Ackerman, 1986).

Why do many species of orchids show high levels of variation? There are several possibilities. First, there could be a breakdown in reproductive isolation mechanisms among closely related species. For example, environmental changes could lead to pollinator-sharing, creating hybrid swarms through introgressive hybridization. Certainly human alterations to the environment can create intermediate habitats that bring two otherwise separated species together. Some well-documented hybrid swarms exist, and others are suspected, but not all variable populations can be attributed to hybridization (Withner, 1974; Ackerman \& Galarza-Pérez, 1991; Azevedo et al., 2006; Jersáková et al., 2006). 
A second possibility is that periodic genetic drift (relaxed selection) may generate variation, particularly when population sizes are small, with even fewer reproductive individuals. Indeed many orchid populations do appear to be small, and fruit set is often low. Natural selection would have to be strong to overcome these conditions. There is some evidence consistent with this mechanism of generating unusually high levels of variation (Tremblay \& Ackerman, 2001; Pellegrino et al., 2007; Salzmann et al., 2007). Genetic drift may also occur in larger populations when the driver of selection is no longer relevant, at least for a time. Although this has been demonstrated for some animals such as Darwin's Galapagos finches and suggested for plants (Grant \& Grant 2006; RiveraMarchand \& Ackerman, 2006), we are not aware of a similar example in orchids.

The third possibility for unusually high levels of variation comes back to natural selection. In most cases it is expected that selection will reduce variation (Endler, 1986), but there are types of selection that can increase variation such as disruptive selection whereby unusual variants are those that have an advantage over common forms. Most flowering plants present a reward to their pollinators who search for food, materials for nest construction, and even resources to attract mates. These come in the form of nectar, pollen, resins, waxes, and even fragrances depending on the pollination system (Simpson \& Neff, 1983). Thousands of orchid species, though, do not offer any pollinator reward whatsoever. These attract pollinators through deception by appearing to offer the resources that pollinators seek. Perhaps the most common form of deceit is the appearance as a food resource (Ackerman, 1986). Precise mimicry is not necessary as pollinators appear to be "wired" to recognize potential food sources. Bees, for example, test the availability of resources through exploratory visits soon after they emerge from their cells and later as their favored plants go out of flower. They visit a number of flowers of a certain type, and if they fail to extract a reward, then they will move to seek alternative resources (Heinrich, 1979). The idea is that if all flowers look the same, then the bees will learn quickly to avoid the species, but if flowers appear different, then it takes the bees longer to learn, and more flowers will be visited as a consequence (Heinrich, 1975). Not only would fruit set be higher in variable populations, the bees would more likely move among plants after each failed exploratory visit resulting in an increase in the probability of crosspollination (Johnson \& Nilsson, 1999; Johnson et al., 2004; Jersáková \& Johnson, 2005). Thus, unusual variants would have the advantage, and their progeny would be better represented in the next generation.

The high levels of variation in deception-pollinated plants has been frequently commented upon, but there is only a single published report that compares population variation in deception and reward plants, and this was a single species pair of Anacamptis (Salzmann et al., 2007). We do have ample unpublished data that indicate deception-pollinated plants are indeed generally more variable (Ackerman, Cuevas, and Hof, unpublished). However, the causes of such high levels of variation usually do not meet the expectations of negative frequency-dependent selection. In fact, only one case has been reported -- Dactylorhiza sambucina (L.) Soó -- and there is some dispute over that (Gigord et al., 2001; Jersáková et al., 2006). Thus far, all other cases studied (all using different methodologies) have failed to detect this type of selection and have indicated that relaxed selection or some other form of selection may be occurring (Ackerman et al., 1997; Aragón \& Ackerman, 2004; Ackerman \& Carromero, 2005). This is not to say that natural selection, or even more specifically negative frequency-dependent selection, has not or will not occur but that only during the course of these particular studies it was not happening. Selection then is either difficult to detect in these plants or occurs for relatively brief periods of time as shown by the spasmodic diversification model (Tremblay et al., 2005). Of course, there is yet another explanation: the methods for detecting selection were not rigorous enough or sufficiently sensitive to detect selection when it occurs.

\section{Variation and plasticity}

Variation is often presumed to be heritable, but the genetics of these traits are rarely examined in orchids, primarily because traditional methods require common garden experiments and crosses among the variants. For this, orchids are not good model systems because of the difficulty in propagating plants from seed (especially terrestrial species) and the relatively long period to first reproduction. Some plasticity in trait 
expression occurs and is not likely directly inherited. For example, inflorescences of most species (not just orchids) have multiple flowers, and frequently the first flowers produced are larger than those that come later, a problem of inflorescence architecture and/or resource allocation (Tremblay, 2006; Herrera, 2009). Plastic responses may also occur in floral production after a pollination event (Ackerman, 1989; Harder and Johnson, 2005). We get around this problem by measuring all flowers of an inflorescence or just the lowermost flower. However, plasticity also occurs in response to environmental heterogeneity. Microhabitat gradients occur within populations, and plants respond accordingly. Environmental conditions can also vary from year to year as habitats go through successional processes or as local climate changes, whether temporary (El Niño or La Niña) or relatively permanent (local urbanization or global changes). Phenotypic responses for given genotypes are well known among plants (Pigliucci, 2001), yet plasticity in orchids has received scant attention. Should plastic versions of traits result in differential fitness, then detecting selection within a population may become additionally problematic. Certainly phenotypic plasticity can blunt the power of selection.

\section{Plasticity in orchids: a test case}

How much plasticity occurs in orchid morphology, and how is this related to fitness? We addressed this question in a recent paper (Morales et al., 2010) by studying a population of Tolumnia variegata (Sw.) Braem, a deception-pollinated twig epiphyte occurring in the Greater Antilles from the Virgin Islands in the east to western Cuba. This is a species for which attempts were made to detect negative frequencydependent selection but without success (Ackerman et al., 1997). In fact, no selection of any kind on any floral characteristic (including fragrance production) was revealed, except for disruptive selection on flowering phenology and weak directional selection on the number of flowers (Sabat and Ackerman, 1996).

Large populations of $T$. variegata are not uncommon and can be found from dry forests to wet montane regions (Ackerman, in press). Plants are small with sympodial growth. Morphological and genetic diversity are high (Fig. 1). Genetic differentiation among populations is low, and estimates of gene flow

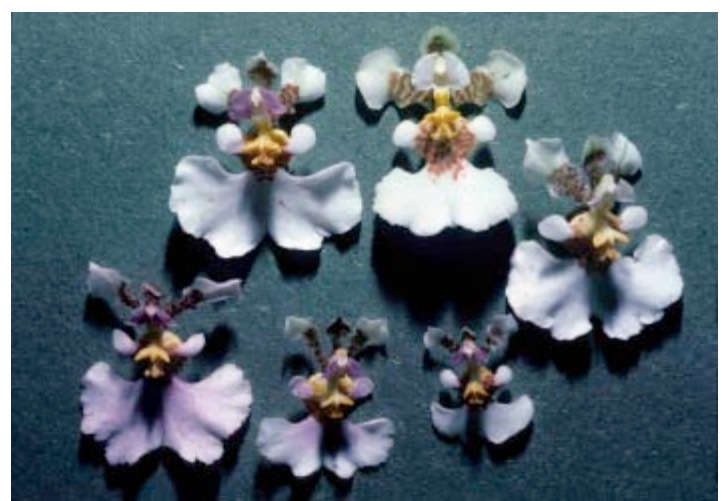

FIGURE 1. Variation in flowers from a single population of Tolumnia variegata in Puerto Rico. Each flower came from a different plant. Photo: James D. Ackerman.

are high, particularly among populations of a given island (Ackerman and Galarza-Pérez, 1991; Ackerman and Ward, 1999). Flowers are self-incompatible, and pollinators are female Centris decolorata (Apidae; Ackerman et al., 1997), presumably deceived by flowers appearing as an oil resource.

To induce plastic responses, we conducted a reciprocal transplant experiment where our environmental gradient of interest was light. Plants grew in the open under full sun and also in the shade. We used 80 plants from two sun sites and 80 plants from two shady sites, all of which were within a $25 \mathrm{~m}$ radius. Prior to transplanting the orchids, we found that shade plants had larger leaves and longer inflorescences but fewer flowers than sun plants. After transplanting, we followed these plants for two years and recorded a number of vegetative, inflorescence, and floral characteristics on each plant and monitored female reproductive success (fruit production). The first year after transplanting (1999) was a wet one, about $200 \mathrm{~mm}$ above normal precipitation. The second year (2000) was a dry one, with precipitation approximately $500 \mathrm{~mm}$ below normal.

Using repeated measures ANOVA to analyze results of the transplant experiment, we found that plant responses were complex (Morales et al., 2010). Leaf characteristics of plants transplanted from sun to shade over time looked much like those that originated and stayed in the shade. Likewise, those that went from shade to sun became more like sun plants. Leaf size in general was strongly affected by drought conditions in the second year. 
Measures of reproductive effort gave mixed results. The number of flowers did not change. Peduncle length was strongly affected by year, whereas the number of inflorescences was more affected by environmental variation.

Floral characteristics we measured were associated with floral display, not with pollination mechanics. All appeared to be plastic, and all were affected by year. Origin of transplants had a significant effect in three of five measures, and flowers in the shade were larger in three of five measures as well.

How did transplants differ in reproductive success? Surprisingly, fruit set was not affected by environment, even though there were significant differences in plant traits between the sun and shade sites. We did not measure male reproductive success where all the action may occur, as has been shown in other orchid systems (Ackerman \& Carromero, 2005).

Because the picture thus far is clear only in the sense that it is muddy, we decided to take an alternative approach to detecting patterns of selection by using the non-parametric, cubic spline regression analysis (see Tremblay et al., 2010). We used data for only those characteristics that showed significant results in the repeated measures ANOVAs. We found that for petal width the overall pattern was for disruptive selection, and this was also reflected in the individual patterns for shade and sun plants. Thus, the two habitats behaved the same with respect to this character. For flower number, there was an overall trend for larger inflorescences to have greater fitness, but this was mostly limited to sun plants because shade plants showed no trend whatsoever. Regardless, this trend is what was detected in an earlier study at the same locality (Sabat and Ackerman, 1996). Finally, we compared lip length and found a negative trend. However, when shade plants and sun plants were analyzed separately, we found that shade plants have a slight positive trend, whereas sun plants show a strong negative trend affecting the overall selection pattern.

When selection across microhabitats is consistent, then evolution has the potential to be fast. But when selection patterns across an environmental gradient are on different trajectories, then the speed of change may be gradual or nil, making it difficult to detect at the population level. Such conflicts may occur across habitats as well as over time.

\section{Conclusions}

The difficulty in detecting selection in orchid populations may be explained by the possibility that selection is not occurring, or as we discussed here, selection may go in different directions depending on where they are in a heterogeneous habitat. The picture can get even more opaque when one considers phenotypic responses over a number of seasons when environmental conditions change from year to year. Using a Bayesian approach with data from this Tolumnia study plus data from a population of Caladenia, Tremblay et al. (2010) found that indeed selection trajectories can vary not only among habitats but also among years, and significantly so. Thus we find yet another reason why selection may be difficult to detect in orchids. The notion that selection need not be operational all the time should come as no surprise. Consequently, we find that these studies are consistent with the spasmodic model of orchid diversification whereby periods of drift (no selection) may be punctuated by brief but strong bouts of selection (Tremblay et al., 2005).

\section{LiTERATURE CITED}

Ackerman, J. D. 1986. Mechanisms and evolution of fooddeceptive pollination systems in orchids. Lindleyana 1 : 108-113.

Ackerman, J. D. 1989. Limitations to sexual reproduction in Encyclia krugii (Orchidaceae). Syst. Bot. 14: 101-109.

Ackerman, J. D. In press. Flora of the Greater Antilles: Orchidaceae. Memoirs of the New York Botanical Garden, Bronx, USA.

Ackerman, J. D. \& W. Carromero. 2005. Is reproductive success related to color polymorphism in a deceptionpollinated, tropical terrestrial orchid? Caribbean J. Sc. 41: 234-242.

Ackerman, J. D. \& M. Galarza-Pérez. 1991. Patterns and maintenance of extraordinary variation in the Caribbean orchid, Tolumnia (Oncidium) variegata. Syst. Bot. 16: 182-194.

Ackerman, J. D. \& S. Ward. 1999. Genetic variation in a widespread, epiphytic orchid: where is the evolutionary potential? Syst. Bot. 24: 282-291.

Aragón, S. \& J. D. Ackerman. 2004. Does flower color variation matter in deception pollinated Psychilis monensis (Orchidaceae)? Oecologia 138: 405-413.

Azevedo, C., E. L. Borba \& C. van den Berg. 2007. Evidence of natural hybridization and introgression in Bulbophyllum involutum Borba, Semir \& F. Barros and 
B. weddellii (Lindl.) Rchb.f. (Orchidaceae) in the Chapda Diamantina, Brazil, by using allozyme markers. Rev. Brasil. Bot. 29: 415-421.

Darwin, C. 1845. Journal of researches into the natural history and geology of the countries visited during the voyage of H.M. S. Beagle round the world under the command of Capt. Fitz Roy, R. N. John Murray, London, UK.

Darwin, C. 1859. On the origin of species by means of natural selection. John Murray, London, UK.

Darwin, C. 1862. On the various contrivances by which British and foreign orchids are fertilised by insects. John Murray, London, UK.

Darwin, C. 1877. The effects of cross and selffertilisation in the vegetable kingdom. John Murray, London, UK.

Endler, J. A. 1986. Natural selection in the wild. Princeton University Press, USA.

Gigord, L. D. C., M. Macnair \& A. Smithson. 2001. Negative frequency-dependent selection maintains a dramatic flower color polymorphism in the rewardless orchid Dactylorhiza sambucina (L.) Soó. Proc. Nat. Ac. Sc. USA 98: 6253-6255.

Grant, B. R \& P. Grant. 2006. Evolution in Darwin's finches: a review of a study on Isla Daphne Major in the Galápagos Archipelago. Zoology 106: 255-259.

Heinrich, B. 1975. Bee flowers: a hypothesis on flower variety and blooming times. Evolution 29: 325-334.

Heinrich, B. 1979. Bumblebee economics. Harvard University Press, Cambridge, Massachusetts, USA.

Herrera, C. M. 2009. Multiplicity in unity. Plant subindividual variation and interaction with animals. University of Chicago Press, Chicago, Illinois, USA.

Jersáková, J. \& S. D. Johnson. 2006. Lack of floral nectar reduces self-pollination in a fly-pollinated orchid. Oecologia 147: 60-68.

Jersáková, J., P. Kindlmann \& S. S. Renner. 2006. Is the colour dimorphism in Dactylorhiza sambucina maintained by differential seed viability instead of frequency-dependent selection? Folia Geobot. 41: 61-76.

Johnson, S. D. \& L. A. Nilsson. 1999. Pollen carryover, geitonogamy, and the evolution of deceptive pollination systems in orchids. Ecology 80: 2607-2619.

Johnson, S. D., C. L. Peter \& J. Ágren. 2004. The effects of nectar addition on pollen removal and geitonogamy in the non-rewarding orchid Anacamptis morio. Proc. Royal Soc., London B 271: 803-809.

Morales, M., J. D. Ackerman \& R. L. Tremblay. 2010. Morphological flexibility across an environmental gradient in the epiphytic orchid, Tolumnia variegata: complicating patterns of fitness. Bot. J. Linn. Soc. 163: 431-446.
Pellegrino, G., A. M. Palermo, M. E. Noce, F. Bellusci, \& A. Musacchio. 2007. Genetic population structure in the Mediterranean Serapias vomeracea, a nonrewarding orchid group. Interplay of pollination strategy and stochastic forces? Pl. Syst. Evol. 263: 145-157.

Pigliucci, M. 2001. Phenotypic plasticity: beyond nature and nurture. The Johns Hopkins University Press, Baltimore, Maryland, USA.

Ramírez, S. R., B. Gravendeel, R. B. Singer, C. R. Marshall $\&$ N.E. Pierce. 2007. Dating the origin of the Orchidaceae from a fossil orchid with its pollinator. Nature 448: 10421045.

Rivera-Marchand, B. \& J. D. Ackerman. 2006. Bat pollination breakdown in a Caribbean columnar cactus, Pilosocereus royenii. Biotropica 38: 635-642.

Sabat, A. \& J. D. Ackerman. 1996. Fruit set in a deceptive orchid: the effect of flowering phenology, display size, and local floral abundance. Amer. J. Bot. 83: 1181-1186.

Salzmann, C. C., A. M. Nardella, S. Cozzolino \& F. P. Schiestl. 2007. Variability in floral scent in rewarding and deceptive orchids: the signature of pollinator-imposed selection? Ann. Bot. 100: 757-765.

Simpson, B. B. \& J. L. Neff. 1983. Evolution and diversity of floral rewards. Pp. 142-159 in: C. E. Jones and R. J. Little (eds.). Handbook of experimental pollination biology. Scientific and Academic Editions, New York, USA.

Tremblay, R. L. 2006. The effect of flower position on male and female reproductive success in a deceptively pollinated tropical orchid. Biol. J. Linn. Soc. 151: 405410 .

Tremblay, R. L. and J. D. Ackerman. 2001. Gene flow and effective population size in Lepanthes (Orchidaceae): a case for genetic drift. Biol. J. Linn. Soc. 72: 47-62.

Tremblay, R.L., J.D.Ackerman \& M.-E. Pérez. 2010. Riding across the selection landscape: fitness consequences of annual variation in reproductive characteristics. Philos. Trans. Royal Soc. London, B 365: 491-498.

Tremblay, R. L., J. D. Ackerman, J. K. Zimmerman \& R. N. Calvo. 2005. Variation in sexual reproduction in orchids and its evolutionary consequences: a spasmodic journey to diversification. Biol. J. Linn. Soc. 84: 1-54.

Wallace, A. R. 1858. On the tendency of varieties to depart indefinitely from the original type. J. Proc Linn. Soc. London 3: 46-50.

Withner, C. L. 1974. Observations on equitant oncidiums as examples of introgressive hybridization. Pp. 34-45 in: H. H. Szmant \& J. Wemple (eds.). First symposium on the scientific aspects of orchids. Chemistry Department, University of Detroit, Detroit, Michigan, USA. 